\title{
Total Brood Removal and Other Biotechniques for the Sustainable Control of Varroa Mites in Honey Bee Colonies: Economic Impact in Beekeeping Farm Case Studies in Northwestern Italy
}

\author{
Teresina Mancuso ${ }^{1, *}$, Luca Croce ${ }^{2}$ and Monica Vercelli ${ }^{1}[$ \\ 1 Department of Agricultural, Forest and Food Sciences, University of Turin, Largo P. Braccini 2, \\ 10095 Grugliasco, Turin, Italy; monica.vercelli@unito.it \\ 2 Independent Researcher, Borgata Baratta 27, 10040 Villardora, Turin, Italy; crusluca@libero.it \\ * Correspondence: teresina.mancuso@unito.it; Tel.: +39-0116708724
}

Received: 15 February 2020; Accepted: 13 March 2020; Published: 16 March 2020

check for updates

\begin{abstract}
Honey bee colonies are affected by many threats, and the Varroa mite represents one of the most important causes of honey bee disease. The control of the Varroa population is managed by different methods, and in recent years, biotechnical practices are considered preferable to chemical approaches in order to safeguard honey bee health and avoid residues in bee products as well as the appearance of acaricide resistance. However, little is known about the economic performance of beekeeping exploitations in relation to the methods used for tackling Varroa. This study aims to investigate the economic impact of total brood removal (TBR) as a biotechnique to keep Varroa mites under control, and compare this to other common biotechniques and chemical Varroa control in numerous Italian beekeeping case studies. A pool of economic and technical indexes was proposed. The proposed index pool can be included in the development of an expert system (such as a decision support system) able to address the optimal management of this very complex activity, which requires natural resources, land protection, capital and high technical skills. The result showed that the adoption of the TBR biotechnique vs. other biotechniques led to an increase in terms of total revenue (increase values ranging from $11 \%$ to $28 \%$ ) even though more labor is needed (increase values ranging from 43 to $83 \mathrm{~min} / \mathrm{hive}$ ) and a loss of honey production could be recorded in some cases. Additionally, the total expenses, represented mainly by supplemental nutrition and treatments with oxalic acid, affected the economic results of the biotechnical practices. The use of biotechniques vs. chemical control resulted in decreased treatment costs and increased feeding costs. The advantages resulting from not using synthetic acaricides (which are dangerous for honey bee and human health as well as the environment) as well as the advantages linked to the production of new nuclei (which are involved in the maintenance of bee stock and counteract the decline in honey bee population) and pollination ecosystem services could make beekeeping farms more resilient over time.
\end{abstract}

Keywords: total brood removal; beekeeping farms; honey bee; varroa control; biotechniques; economic result; management; organic regime

\section{Introduction}

Beekeeping, compared to other agricultural activities, seems to have been investigated less from an economic point of view because it is practiced, in most cases, by hobbyists while professionals exist in more limited numbers. In the European Union, beekeeping as an economic activity can be a source of income support and family self-production, but little is known regarding the economic consequences and even less about how these may compare from country to country. Institutions consider beekeeping 
very peculiar compared to other agricultural activities, and the European Union implements three-year plans to support activities that support beekeepers [1]. In the last 15 years, research has focused more on the value of the ecosystem services that beekeeping provides for agriculture and biodiversity, rather than on the profitability of beekeeping farms, especially those that operate professionally. The European honey market is lively and dynamic, with beekeeping being a widely developed activity in the European Union, both at professional (beekeepers with over 150 hives) and hobby levels. There are around 620,000 beekeepers in the European Union, of which around 95-97\% are non-professional, accounting for around $67 \%$ of EU hives [2,3]. Honey production is estimated to be close to 200,000 tons. Beekeeping is also associated with the production of other products such as wax, royal jelly, propolis, queens, and swarms. In relation to the rest of the European Union, Italy shows a substantial comparative disadvantage in the trade of this product [4], and imports honey from abroad, especially from Argentina and Hungary, where it can be produced at lower costs. Consumers are interested in the quality of honey [5,6], in other bee products [7], and also in where the honey is produced $[8,9]$. Organic honey is increasingly appreciated by European consumers [8].

The main threats facing the beekeeping sector are linked to honey bee health and vitality issues. The causes of honey bee (Apis mellifera L.) colony losses are multifactorial (diseases, parasites and viruses, beekeeping practices, climatic factors, and environmental factors such as nectar and pollen scarcity, and the structure of modern agricultural landscapes) [10-12], and Varroa (Varroa destructor Anderson and Trueman) is one of the major threats (Figure 1), including indirectly by transmitting several viruses [13-16].

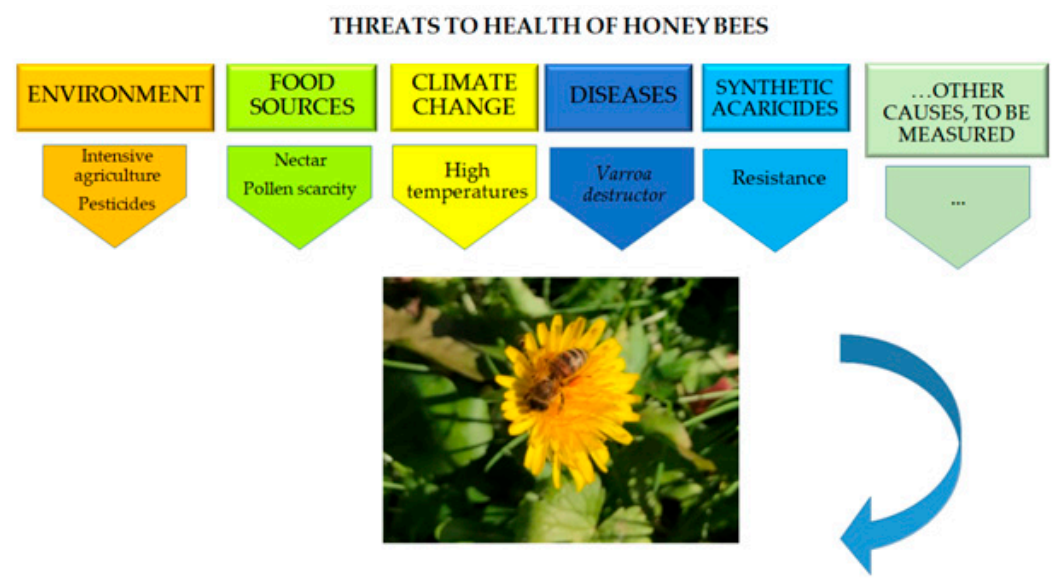

POSSIBLE MITIGATIONS TO STRENGTHEN HONEY BEE HEALTH

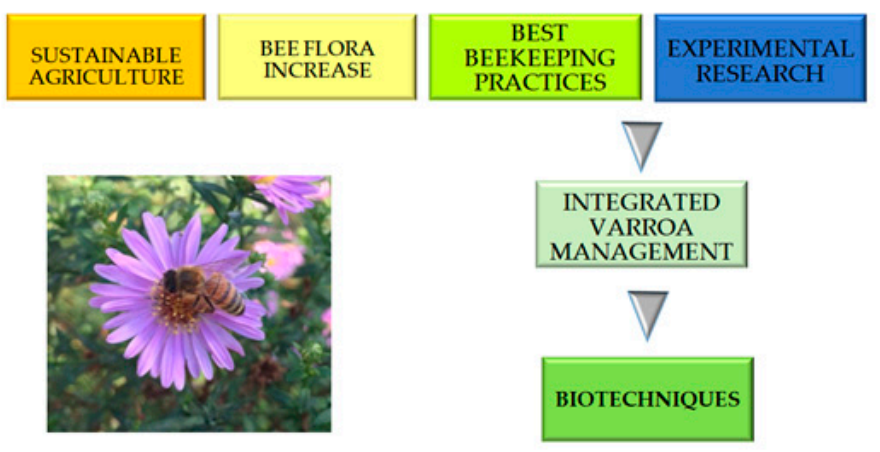

Figure 1. Threats affecting honey bee health and possible mitigations.

Varroa control is an integrated part of beekeeping management to maintain colony survival. Different methods are combined and used one or more times during the season [17]. A wide range of different synthetic acaricides to control mite populations is used, such as the organophosphate coumaphos, pyrethroids tau-fluvalinate, formamidine amitraz, and flumethrin [18,19]. However, 
the appearance of acaricide resistance and the risk of contamination of the bee product have led to increased interest in alternative control strategies against Varroa [20-22]. In recent years, great attention has focused on the use of environmentally safe chemicals (such as organic acids), essential oils, and biotechnical methods, and integrated management is recommended [23-27].

Biotechniques include drone brood removal, queen caging, and, most recently, total brood removal; combining the artificial brood-free condition with organic acid applications is a sustainable strategy for tackling Varroa mites. The effectiveness of these approaches has been demonstrated in previous research [27-30]. Biotechniques require additional work from the beekeeper, to a lesser or greater extent, and their adoption always requires a careful organization of the farm's resources, and in particular the labor [31].

To the best of our knowledge, there are no studies that have focused on the economic results of beekeeping farms that adopt one or more of the methods to mitigate Varroa, from the use of acaricides to biotechniques. As is well known, a decline in the number of honey bee colonies causes important economic losses, and the increased costs spent to treat bee diseases reduce the profitability of the sector. In 2010, an online survey targeting EU beekeepers and beekeeper associations was carried out to collect useful data on the perception of measures to support the EU apicultural sector [1]. The results of the survey showed that beekeepers attached high importance toward two measures supporting them to maintain or increase their production capacity and productivity: technical assistance and the fight against Varroa.

Beekeepers and their associations agreed about the high costs of the treatments available and the need for more active medicines to combat Varroa. The survey showed that about $33 \%$ of beekeepers believed that control of Varroa accounted for between $10 \%$ and $20 \%$ of the cost of production [1]. For $19 \%$ of beekeepers, this accounted for more than $20 \%$. The study does not specify how the cost of Varroa control is formed, but it may depend on the used substances as well as the employed techniques. In fact, over the years, beekeepers have sought and continue to seek methods to keep Varroa under control. The cost is therefore not always only linked to the administration of medicines but also to different methods implemented in apiaries, and research on this issue is lacking. By contrast, the pollination services' side has been widely studied. Pilati and Prestamburgo [32] analyzed the costs, revenues, and profit concerning migratory beekeeping and the resulting joint outputs, namely non-marketable output (such as ecosystem services) and marketable output (such as honey production). Farmers in sub-Saharan Africa are vulnerable to any reductions in crop productivity as they cultivate very small parcels that are highly dependent on the services provided by pollination, as studied by some authors [33], in order to highlight the impact on revenues, costs, and income incurred when biodiversity is threatened. Blanc et al. [34] analyzed costs and revenues related to the introduction of pollination services in some rural areas in Italy. Hein [35] discussed the appropriate assessment methods and the approach to the scale of analysis of economic value for pollination at different scales (local, national, and global). Pollination is essential for many crops, even for plants that produce particular substances such as essential oils, and the role of honey bees remains fundamental [36,37]. Highly variable depending on the crop and the market conditions at local scale, pollination services range from $1 \%$ to $16 \%$ of the market value of agricultural production at the national scale. Gallai and colleagues [38] assessed that "the total economic value of pollination worldwide amounted to $€ 153$ billion, which represented $9.5 \%$ of the value of the world agricultural production used for human food in 2005". Other authors [39] have examined the full economic costs of providing pollination services to crops in the United Kingdom and verified that beekeepers rarely received payment for these services, or if they received payment, this was 86-149 times less than the benefit for apple growers.

The economic performance side, taking into account revenues and costs at the beekeeping farm scale, appears to have been less analyzed. Saner and colleagues [40] explored the structure of Turkey's beekeeping sector. While the constraints on the development of high-quality honey production were highlighted, the costs and revenues of farms were examined in order to identify the most appropriate economic dimensions. A study carried out in Yucatan, Mexico, showed the structure of costs incurred 
for the production of organic and conventional honey, and the study discussed the fixed or variable nature of certain items [41]. In Iran, some authors investigated the influence of credit, knowledge, and education level, and visits to demonstrations significantly influenced the innovation adoption of the box hive. Total costs and revenues in the Karaj area were analyzed for traditional and transitional hives compared to modern hives: the findings showed that innovation demands expensive beekeeping equipment and accessories as well as skilled personnel [42]. The EU Commission highlighted that the situation of beekeeping varies across countries [1] and, hence, the biotechnical and conventional control of Varroa could be managed in different ways, and the solutions adopted in different countries were showed.

Under the Interreg Alcotra Project "INNOV'API-Innovation sanitarie pour la durabilite des exploitations apicoles" (2017-2020), the use of total brood removal (TBR)—an innovative biotechnique to control Varroa mites and associated viruses as a way to improve the health of honey bees-was investigated and compared to the use of chemical approaches. This study aims to assess the economic impact in Italian beekeeping farm case studies that have recently adopted the innovative TBR biotechnique as compared to other common biotechniques and chemical Varroa control methods. By calculating the economic and technical parameters, a pool of economic and technical indexes was proposed. From these indexes and other empirical data collected in apiaries, a decision support system that enables beekeepers and technical advisors to choose the best technique according to the organization and management features of the beekeeping exploitation can be developed.

\section{Materials and Methods}

In order to investigate the economic performance of the analyzed beekeeping farms and the economic impact of total brood removal (TBR) as a biotechnique used for Varroa control in beekeeping exploitations, and to then compare the results obtained by the different used methods, beekeepers in two provinces of Piedmont (Northwestern Italy) in the Alpine area of the INNOV'API Interreg Alcotra project were contacted. Some of them were chosen on the basis of having adopted the TBR biotechnique in apiaries as a strategy to keep Varroa under control, while other beekeepers using different methods to fight Varroa were also selected.

Data about some features of the Italian and French (including Alcotra space) beekeeping farms are provided in Tables 1 and 2, specifying 4 size classes of hives and the types of products and their prices [3]. As a result of these two key points, i.e., biotechnique/chemical Varroa control and the size of hives, the composition of dissimilar production costs could be derived as well as the composition of revenues. 
Table 1. Honey bee colonies (livestock), mortality, sizes of apiaries, number of beekeepers, and beekeeper activities in France and Italy (2010).

\begin{tabular}{|c|c|c|c|c|c|c|c|c|c|c|}
\hline \multirow{2}{*}{ Countries } & \multirow{2}{*}{$\begin{array}{l}\text { N. Colonies } \\
\text { (\% of } \\
\text { Total EU) }\end{array}$} & \multirow{2}{*}{$\begin{array}{l}\text { Colonies Mortality } \\
\text { (\% and Origin of } \\
\text { the Data) }\end{array}$} & \multicolumn{4}{|c|}{$\begin{array}{l}\text { Size of Colonies (col) (\% of Total } \\
\text { Colonies in Each Country) }\end{array}$} & \multirow{2}{*}{$\begin{array}{l}\text { N. Beekeepers } \\
\text { (\% of Total EU) }\end{array}$} & \multicolumn{3}{|c|}{ Beekeepers Activities } \\
\hline & & & $<50 \mathrm{col}$ & $51-150$ col & $151-300$ col & $>300$ col & & $\begin{array}{l}\text { Professional } \\
\text { Beekeepers }\end{array}$ & $\begin{array}{l}\text { Part-time } \\
\text { Beekeepers }\end{array}$ & $\begin{array}{c}\text { Hobby } \\
\text { Beekeepers }\end{array}$ \\
\hline France & $\begin{array}{c}1,346,575 \\
(9.7 \%)\end{array}$ & $20^{\mathrm{a}} / 20^{\mathrm{b}}$ & 93 & 4 & 2 & 1 & $69,237(11.2 \%)$ & 3 & 7 & 90 \\
\hline Italy & $\begin{array}{c}1,127,000 \\
(8.1 \%)\end{array}$ & $19^{\mathrm{a}} / 22.5^{\mathrm{c}}$ & 60 & 20 & 10 & 10 & $70,000(11.3 \%)$ & 10 & 20 & 70 \\
\hline
\end{tabular}

a: Coloss questionnaire; b: beekeeper association; c: veterinary services. Source: modified from Chauzat et al. (2013) [3].

Table 2. French and Italian products by honey bees, trade, and prices of honey (2010).

\begin{tabular}{|c|c|c|c|c|c|c|c|c|c|c|}
\hline \multirow[b]{2}{*}{ Countries } & \multicolumn{6}{|c|}{ Products } & \multicolumn{4}{|c|}{ Market of Honey } \\
\hline & Honey $(t)$ & $\begin{array}{c}\text { Honey }(t / 100 \\
\text { Colonies) }\end{array}$ & Pollen (kg) & $\begin{array}{l}\text { Royal Jelly } \\
\text { (kg) }\end{array}$ & $\begin{array}{c}\text { Queen } \\
\text { (Number) }\end{array}$ & $\begin{array}{c}\text { Swarm } \\
\text { (Number) }\end{array}$ & Import (t) & Export $(t)$ & Retail Price (€/kg) & $\begin{array}{c}\text { Wholesale Price } \\
(\mathrm{f} / \mathrm{kg})\end{array}$ \\
\hline France & 20,000 & 1.5 & Not available & 7000 & Not available & Not available & 28,000 & 5000 & Between 6 and 10 & Between 3 and 6 \\
\hline Italy & 23,000 & 2.0 & Not available & 4000 & 350,000 & Not available & 10,000 & 3000 & Between 6 and 9 & Between 3 and 5 \\
\hline
\end{tabular}

Source: modified from Chauzat et al. (2013) [3]. 
In general, the methods used by beekeepers interviewed were (1) total brood removal (TBR), (2) queen caging (QC), (3) old queen replacement by royal cell (RC), (4) chemical treatments (amitraz/fluvalinate) (CH), and (5) organic treatment (ApilifeVar) (THY). The first three are biotechnical practices that allow the creation of an artificial brood interruption period in the colony and thus interrupting Varroa population growth. Oxalic acid was used as a treatment by all of the beekeepers, either alone or in combination with biotechnical techniques. THY was gathered in biotechnical practices because it is considered a natural compound like oxalic acid [13]. Five beekeeping farms applied a combination of the cited techniques to fight Varroa, while only one farm applied TBR on the totality of the beehives, as shown in Table 3, where the numbers from 1 to 6 identify the farms that have applied the TBR with or without other biotechniques. In these beekeeping farms, TBR was applied in $16-36 \%$ of hives and, hence, the comparison of TBR versus other biotechniques was performed with the same cost structure. This meant that it was possible to compare the economic results within the same beekeeping farm where two or three biotechniques were applied (farms no. 1-6 in Table 3). In the three other farms indicated as farms no. 7-9 in Table 3, where only chemical treatment was applied, TBR was compared to the chemical control.

Table 3. Identification and analysis of number, size, and Varroa control methods related to the beekeeping exploitations.

\begin{tabular}{ccc}
\hline Farms & Size of Beekeeping Farms (Colonies + Nuclei) & Varroa Control Technique * \\
\hline 1 & 1070 & TBR, QC, RC \\
2 & 1000 & TBR, QC, RC \\
3 & 210 & TBR, RC \\
4 & 240 & TBR, QC, RC \\
5 & 23 & TBR, THY \\
6 & 190 & TBR \\
7 & 629 & $\mathrm{CH}$ \\
8 & 1300 & $\mathrm{CH}$ \\
9 & 165 & $\mathrm{CH}$ \\
\hline
\end{tabular}

* TBR: total brood removal; QC: queen caging; RC: royal cell; CH: chemical treatments; THY: ApilifeVar treatment.

The locations of the nine beekeeping farms are represented in the map (Figure 2) where the position of the nine case studies (two farms are near two of the other farms, thus there are only seven locations visible on the map) in the two provinces (Turin and Cuneo) are delimited with respect to the Piedmont region, Italy.

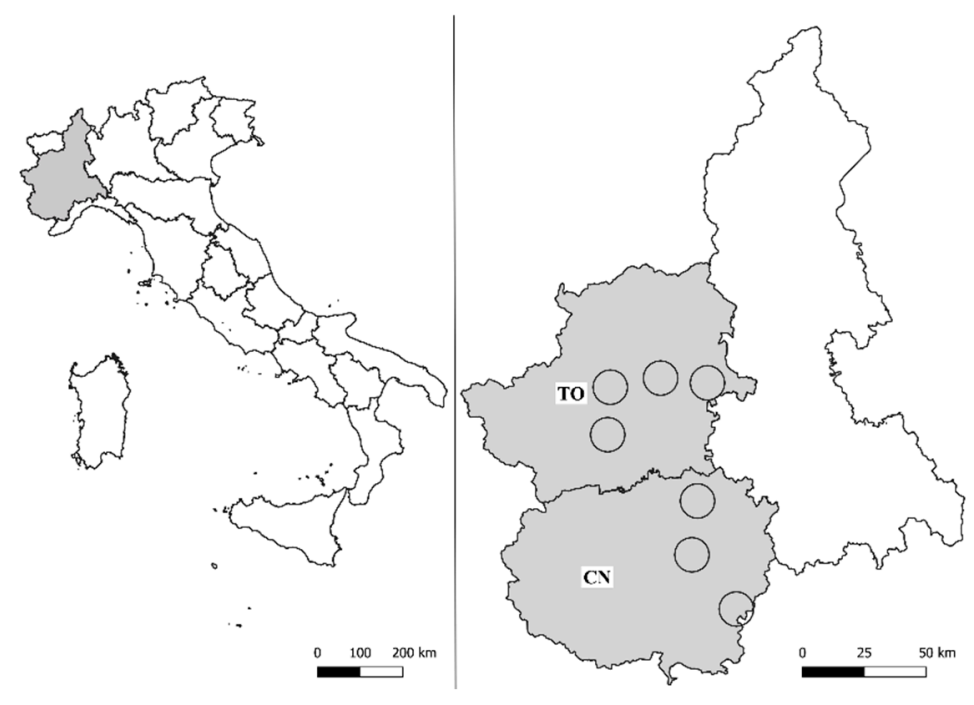

Figure 2. The location of the center of the beekeeping farms case studies within the Cuneo and Turin provinces of the Piedmont region, Italy. 
The considered exploitations were heterogeneous in size and characterized by professional activity and migratory beekeeping. Some of them had adopted organic regimes. The beekeepers were interviewed about farm management, the production and sales phases, and the Varroa control techniques. The balance sheet model [43] was tailored to the features of a beekeeping farm. During the interviews, data relating to the costs and revenues of the beekeeping farms were collected. At the same time, economic and technical indexes were derived from the data. The economic analysis was carried out by the 2015-2017 year average. TBR was applied in the beekeeping farms in 2017. Data were collected to investigate the aspects of the production process impacted by the TBR technique and other bio-techniques.

In this work, some indexes such as total revenues (honey and other bee products, i.e., wax, pollen, nuclei, bee queens, stocks, income/losses of honey bee stocks, and others, see Equation (1)), total expenses (see (2)), labor, and nucleus values are discussed. The technique has an impact on some aspects of the production process that concern the indexes mentioned above. For the determination of manpower in terms of time (excluding freight), beekeepers were asked about the operations that were carried out to execute the different management techniques.

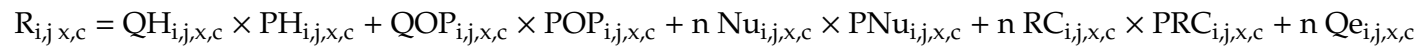

$$
\begin{aligned}
& \times \mathrm{PQe}_{\mathrm{i}, \mathrm{j}, \mathrm{x}, \mathrm{c}}+\mathrm{s}
\end{aligned}
$$

where:

i: total brood removal biotechnique

$\mathrm{j}$ : queen caging biotechnique

$\mathrm{x}$ : royal cell insertion biotechnique

c: chemical technique

R: revenues; $\mathrm{QH}$ : quantity of honey; $\mathrm{PH}$ : price of honey; QOP and POP: quantity and price of other bee product (wax, pollen, propolis, etc.); n: number of (nuclei, queens, royal cells); Nu: nucleus production; PNu: price of nucleus; RC: royal cell; PRC: price of royal cell; Qe: queen caging; PQe: price of queen caging; s: yearly honey bee stock variation.

The studied biotechniques differed, overall, in terms of expense items, and, hence, the following expenses were recorded and compared (see Equation (2)): combs and/or frames with foundations, feeding, treatments, royal cells and queens, and other expenses.

$$
\begin{aligned}
& \operatorname{Exp}_{\mathrm{i}, \mathrm{j}, \mathrm{x}, \mathrm{c}}=\mathrm{FQ}_{\mathrm{i}, \mathrm{j}, \mathrm{x}, \mathrm{c}} \times \mathrm{FP}_{\mathrm{i}, \mathrm{j}, \mathrm{x}, \mathrm{c}}+\mathrm{CFQ}_{\mathrm{i}, \mathrm{j}, \mathrm{x}, \mathrm{c}} \times \mathrm{CFP}_{\mathrm{i}, \mathrm{j}, \mathrm{x}, \mathrm{c}}+\mathrm{RCQ}_{\mathrm{i}, \mathrm{j}, \mathrm{x}, \mathrm{c}} \times \mathrm{RCP}_{\mathrm{i}, \mathrm{j}, \mathrm{x}, \mathrm{c}}+\mathrm{QeQ}_{\mathrm{i}, \mathrm{j}, \mathrm{x}, \mathrm{c}} \times \mathrm{QeP}_{\mathrm{i}, \mathrm{j}, \mathrm{x}, \mathrm{c}}+\mathrm{TQ}_{\mathrm{i}, \mathrm{j}, \mathrm{x}, \mathrm{c}} \\
& \times \mathrm{TP}_{\mathrm{i}, \mathrm{j}, \mathrm{x}, \mathrm{c}}+\mathrm{s}
\end{aligned}
$$

where:

i: total brood removal biotechnique

$\mathrm{j}$ : queen caging biotechnique

$\mathrm{x}$ : royal cell insertion biotechnique

c: chemical technique

Exp: expenses; FQ: feeding quantity (sugar syrup and candy); FP: feeding price; CFQ: combs and frames with foundations quantity; CFP: combs and frames with foundations price; RCQ: royal cells quantity; RCP: royal cells price; QeQ: queens quantity; QeP: queens price; TQ: treatments quantity (oxalic acid and other treatments); TP: treatments price; s: yearly honey bee stock variation.

The nucleus cost production and revenue in applying the TBR technique were also investigated, and specific attention was addressed to the manpower time dedicated to each operation. The production of nuclei is usual during the honey bee season, and is a feature of the TBR technique. The production cost of the nuclei derived by the TBR biotechnique was calculated considering the following items: feeding, treatments, royal cells and queens, manpower, and loss of honey production. 
During the collection of the data, 26 economic and technical indexes were developed as shown in Table 4. Indexes can inform an expert system. The indexes always refer to one hive as a unit. As an example, for this work, some selected indexes-three economic (expenses, revenues, nuclei revenues) and one technical (labor) - that were calculated for the beekeeping farm case studies are shown in the Results section and discussed (Table 4).

Table 4. Fine-tuned economic and technical indexes to assess the impact of biotechniques and conventional management for Varroa control in beekeeping farms.

\begin{tabular}{|c|c|}
\hline Index & Unit of Measure \\
\hline Net income per hive & $€$ \\
\hline Honey production cost per kilogram & $€$ \\
\hline \multicolumn{2}{|l|}{ Total Brood Removal (TBR) } \\
\hline Manpower (excluding freight) & Minutes/hive \\
\hline Manpower cost & $€ /$ hive \\
\hline Total expenses & $€ /$ hive \\
\hline Mother colony feeding expenses & $€ /$ hive \\
\hline Nucleus feeding expenses & $€ /$ nucleus \\
\hline Mother colony treatment expenses & $€ /$ colony \\
\hline Nucleus treatment expenses & $€ /$ nucleus \\
\hline Mortality rate of nuclei & $\%$ \\
\hline Total revenues & $€ /$ hive \\
\hline Nuclei (assembled by TBR) revenues & $€ /$ hive \\
\hline Net income per hive & $€ /$ hive \\
\hline Net income difference between TBR and other techniques & $€ /$ hive \\
\hline Labor difference between TBR and other techniques applied (time) & Minutes/hive \\
\hline Labor difference between TBR and other techniques applied (cost) & $€ /$ hive \\
\hline Revenue per nucleus by TBR & $€$ \\
\hline Honey production loss for TBR nucleus production & $€$ \\
\hline Revenue per TBR nucleus (including value of nucleus and honey loss) & $€$ \\
\hline \multicolumn{2}{|l|}{ Other Biotechniques (QC; RC; CH; THY) } \\
\hline Manpower involved & Minutes/hive \\
\hline Manpower cost & $€ /$ hive \\
\hline Colony and nucleus feeding expenses & $€ /$ hive \\
\hline Treatment expenses for colony and nucleus & $€ /$ hive \\
\hline Total gross revenue per hive & $€ /$ hive \\
\hline Honey yield per colony & $\mathrm{kg}$ \\
\hline Net income from honey and other bee products & $€ /$ hive \\
\hline
\end{tabular}

The analyzed beekeeping farms were divided into classes according to their number of hives, and four economic and technical indexes were defined.

When a beekeeping farm has to make choices related to management of Varroa control, it must acquire a series of data and information in order to adopt optimal changes. A model assessing economic sustainability to adopt the TBR biotechnique was developed (Figure 3), finding answers to these questions: Is TBR economically viable? Can TBR be routinely adopted on the farm? Is it preferable to carry out TBR on all hives? Conversely, can it be advantageous to apply it only on a part of the hives? How much manual work do they require? What economic advantage is obtained by the use of biotechniques that replace the administration of medicines? How much does it impact on the beekeeping farm organization? How much does it cost to manage and implement biotechniques? 


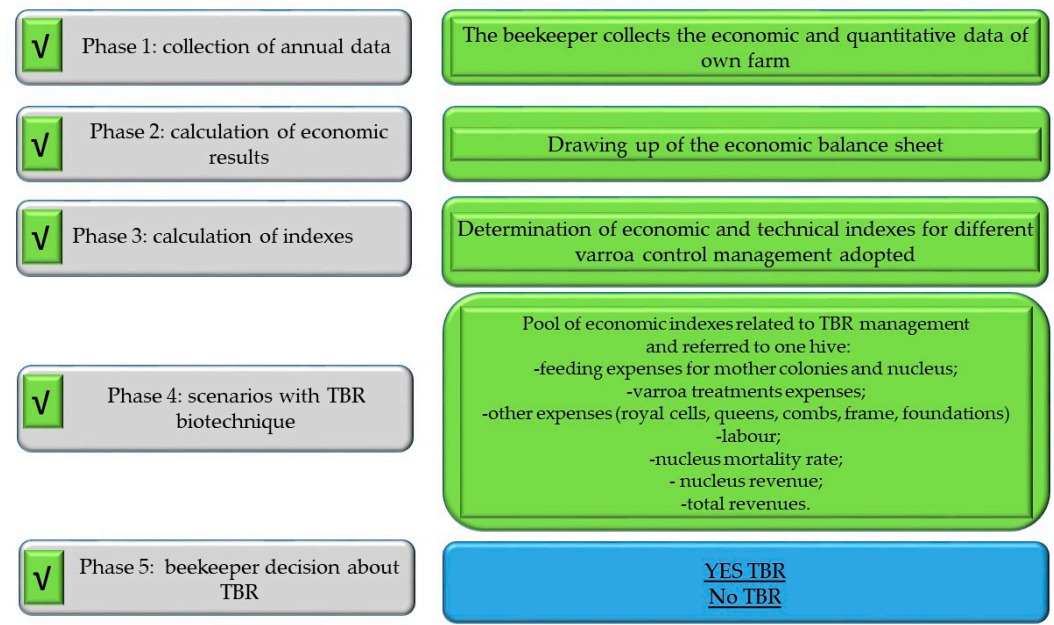

Figure 3. Phases assessing the adoption of the total brood removal (TBR) biotechnique as a Varroa control method.

\section{Results}

\subsection{Indexes Assessing Biotechniques and Chemical Varroa Control}

\subsubsection{Biotechniques: Total Revenues}

The data show that the different adopted biotechniques to fight Varroa impacted the total revenue. The TBR technique determined an increase in total gross revenue value due to the production of new nuclei according to the number of nuclei that survived to the end of the bee season. The values varied from 252 to $450 € /$ hive (Table 5). The difference between the TBR total revenue value and the total revenue of other biotechniques varied from 45 to $69 € /$ hive, with an increase in total revenue value ranging from $11 \%$ to $28 \%$ (Table 5). In farms no. 1 and 4 , the TBR technique led to a reduction in honey production compared to hives managed by other management techniques. The loss of honey production as a result of the adoption of TBR varied from $24 € /$ hive (farm no. 1 ) to $27 € /$ hive (farm no. 4). On the contrary, no differences in honey production were recorded in farms 2, 3, 5, and 6.

Table 5. Total revenues of the beekeeping farms adopting biotechniques to control Varroa mites.

\begin{tabular}{ccccc}
\hline Farms & $\begin{array}{c}\text { Total Revenues of the } \\
\text { TBR Technique } \\
(\boldsymbol{€} / \text { hive) }\end{array}$ & $\begin{array}{c}\text { Total Revenues of } \\
\text { Other Biotechniques } \\
(\boldsymbol{\epsilon} / \text { hive) }\end{array}$ & $\begin{array}{c}\text { Total Revenues } \\
\text { Difference (€/hive) }\end{array}$ & $\begin{array}{c}\text { Increase in Total } \\
\text { Revenues Due to the } \\
\text { TBR Technique (\%) }\end{array}$ \\
\hline 1 & 313 & 244 & 69 & 28 \\
2 & 313 & 256 & 57 & 22 \\
3 & 450 & 405 & 45 & 25 \\
4 & 319 & 255 & 45 & 22 \\
6 & 252 & 207 & 0 & - \\
\hline
\end{tabular}

\subsubsection{Biotechniques: Total Expenses}

The main expenses involved in the execution of TBR are related to supplemental nutrition, combs and frames with foundations, royal cells and queens, and treatments (oxalic acid, OA). The values of total expenses ranged from 26 to $45 € /$ hive (Table 6). The most important expense was represented by the feed (sugar syrup and candy) distributed to both the mother colonies and nuclei both immediately after the execution of the TBR technique and in the autumn and winter periods. The incidence of this item varied from $39 \%$ to $53 \%$. Moreover, the expenses for the use of combs and/or frames with foundations ranged from $12 \%$ to $33 \%$, and the royal cell and queen production costs or purchases to construct the nuclei also affected the total expenses with values ranging from $0 \%$ to $18 \%$. The treatment 
expenses also affected the total expenses in a range from $11 \%$ to $20 \%$. Other minor expenses influenced total expenses as shown in Table 6.

Table 6. Total expenses applying the total brood removal (TBR) technique against Varroa mites.

\begin{tabular}{ccccccc}
\hline Expense Items & \multicolumn{5}{c}{ Farms } \\
\cline { 2 - 7 } & $\mathbf{1}$ & $\mathbf{2}$ & $\mathbf{3}$ & $\mathbf{4}$ & $\mathbf{5}$ & $\mathbf{6}$ \\
\hline Total expenses (€/hive) & 45 & 41 & 26 & 37 & 29 & 26 \\
Feeding expense (\%) & 39 & 52 & 46 & 39 & 52 & 53 \\
Combs and frames with foundations expense (\%) & 24 & 17 & 33 & 28 & 12 & 22 \\
Royal cells and queens expense incidence to produce nuclei (\%) & 15 & 14 & 0 & 18 & 0 & 0 \\
Treatment (OA) expense (\%) & 13 & 11 & 18 & 12 & 20 & 14 \\
Other expenses (\%) & 9 & 6 & 3 & 3 & 16 & 11 \\
\hline
\end{tabular}

\subsubsection{Biotechniques: Manpower}

The TBR biotechnique is more labor-demanding than the other analyzed management techniques. The manpower required to carry out the different Varroa management techniques varies between farms, and this variability is due to both the use of different techniques and the execution of the same technique being carried out in different ways depending on the farm organization and technical skill of the beekeeper. A range from 43 to $83 \mathrm{~min} /$ hive was needed for the TBR technique, compared to the 30-48, 35-37, and $31 \mathrm{~min} /$ hive for the execution of the QC, RC, and THY techniques, respectively (Table 7).

Table 7. Manpower (minutes/hive) needed for the application of the total brood removal (TBR) technique in comparison with the other techniques.

\begin{tabular}{ccccc}
\hline Farms & $\begin{array}{c}\text { Manpower TBR } \\
\text { (minutes/hive) }\end{array}$ & $\begin{array}{c}\text { Manpower QC } \\
\text { (minutes/hive) }\end{array}$ & $\begin{array}{c}\text { Manpower RC } \\
\text { (minutes/hive) }\end{array}$ & $\begin{array}{c}\text { Manpower THY } \\
\text { (minutes/hive) }\end{array}$ \\
\hline 1 & 61 & 30 & 35 & $/$ \\
2 & 64 & 41 & 37 & $/$ \\
3 & 83 & 48 & $/$ & $/$ \\
4 & 75 & 32 & $/$ & 31 \\
5 & 43 & $/$ & $/$ & $/$ \\
6 & 60 & $/$ & & \\
\hline
\end{tabular}

\subsubsection{Biotechniques: TBR Nucleus Gross Income}

The revenue for a unit of organic nucleus was equal to $€ 130$; the gross income of the nuclei derived by the TBR technique varied from 47 to $79 € /$ nucleus. The costs incurred for feeding, labor, royal cells/queens, and used combs/foundations had the greatest impact on the gross income of the nuclei and, also, the loss of honey production and the survival of the nuclei sometimes influence this parameter (Table 8). As an example, the data show that this influence occurred in farm no. 3 (gross income: $79 € /$ nucleus, mortality: $52 \%$ ), while in farm no. 1 , the gross income was equal to $47 € /$ nucleus and a mortality rate of $15 \%$ led to a better result.

Table 8. Gross income of nuclei derived by the total brood removal (TBR) technique and some items of cost production incidence on the revenue of nuclei (\%).

\begin{tabular}{ccccccc}
\hline \multirow{2}{*}{ Items } & \multicolumn{7}{c}{ Farms } \\
\cline { 2 - 7 } & $\mathbf{1}$ & $\mathbf{2}$ & $\mathbf{3}$ & $\mathbf{4}$ & $\mathbf{5}$ & $\mathbf{6}$ \\
\hline Gross Income Nucleus (€/nucleus) & 47 & 74 & 79 & 51 & 70 & 71 \\
Feeding incidence (\%) & 14 & 17 & 9 & 11 & 14 & 12 \\
Treatment incidence (\%) & 4 & 4 & 4 & 4 & 5 & 3 \\
Royal cells/queens incidence (\%) & 5 & 5 & 0 & 5 & 0 & 0 \\
Combs and frames incidence (\%) & 9 & 7 & 13 & 9 & 5 & 7 \\
Manpower incidence (\%) & 10 & 10 & 13 & 12 & 8 & 12 \\
Honey production loss incidence (\%) & 19 & 0 & 0 & 21 & 0 & 0 \\
\hline
\end{tabular}




\subsubsection{Chemical Control of Varroa}

The total revenue values in the farms that applied only a chemical control $(\mathrm{CH}$, farms no. 7,8 , and 9) were $233 € /$ hive (farm no. 7 ), $231 €$ /hive (farm no. 9), and $387 € /$ hive (farm no. 8). Regarding the manpower, the results were $29 \mathrm{~min}$ (farm no. 7), $19 \mathrm{~min}$ (farm no. 9), and $21 \mathrm{~min}$ (farm no. 8). The comparison of data between the TBR biotechnique vs. chemical control permits to observe that there is evidence of a decrease in the expenses related to treatments with oxalic acid (from $33 \%$ to $56 \%$ ) and an increase in the expenses related to feeding (from $+71 \%$ to $+214 \%$ ) (Table 9).

Table 9. Comparison between the expenses of the TBR biotechnique and chemical practice (\% variation).

\begin{tabular}{ccccc}
\hline Farms & Treatments (€/hive) & Feeding (€/hive) & $\begin{array}{c}\text { Decrease in Cost } \\
\text { for TBR vs. CH } \\
\text { Treatments (\%) }\end{array}$ & $\begin{array}{c}\text { Increase in Cost } \\
\text { for TBR vs. CH } \\
\text { Feeding (\%) }\end{array}$ \\
\hline 1 & 6 & 18 & -33 & 157 \\
2 & 5 & 22 & -44 & 214 \\
3 & 5 & 12 & -44 & 71 \\
4 & 5 & 13 & -44 & 114 \\
5 & 6 & 15 & -33 & 100 \\
6 & 4 & 14 & -56 & $/$ \\
\hline $\begin{array}{c}\text { Average CH Treatments, } \\
\text { farms no. 7-9 }\end{array}$ & 9 & 7 & $/$ & \\
\hline
\end{tabular}

\subsection{Developing a Decision Support System}

The basic idea was to provide support for the potential French or Italian beekeeper that wants to control Varroa with different management methods other than chemical control alone. Therefore, the following procedure is proposed: (1) Follow the steps illustrated in the method (Figure 3); (2) Identify the class of hives into which it falls; (3) Decide the percentage of hives on which the TBR may be applied. Then, with the help of all of the collected data and information, examine Figures 4 and 5 and observe the variations of the selected indexes that may occur in a beekeeping farm of the same class. (4) Different scenarios of revenue and cost analyses can be developed considering the overall manpower needed for each technique to control Varroa. The index pool can provide data to an expert system to launch the basis for setting up a dedicated decision support system (DSS).

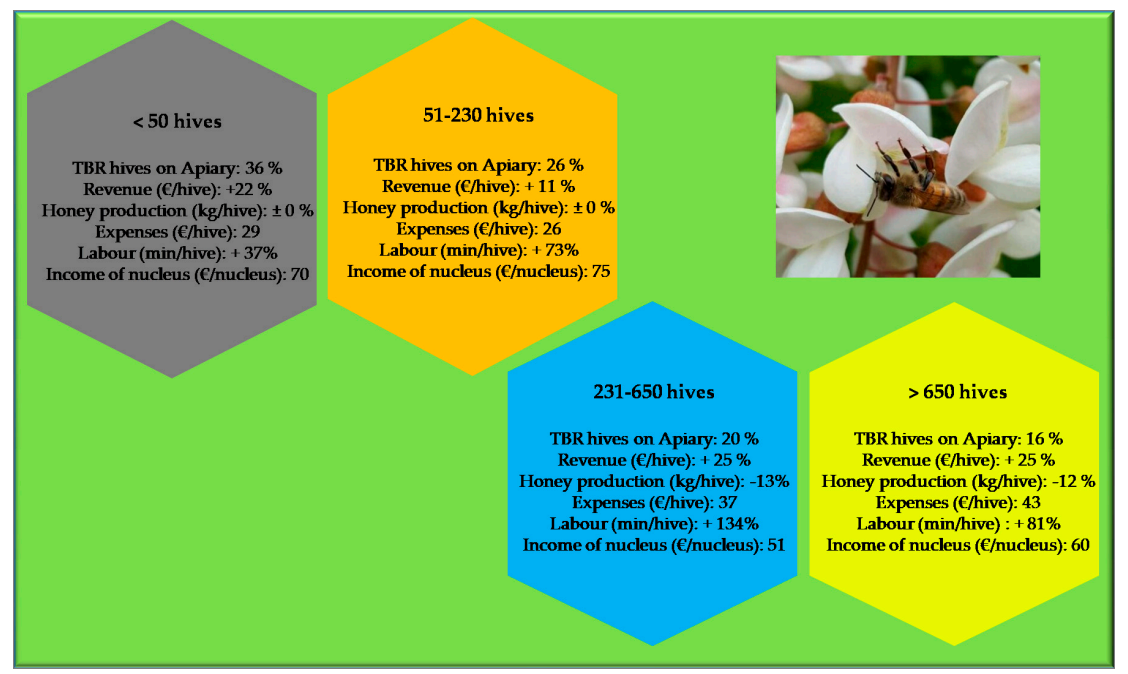

Figure 4. Economic performance of beekeeping farms adopting the TBR in comparison with other biotechniques. 


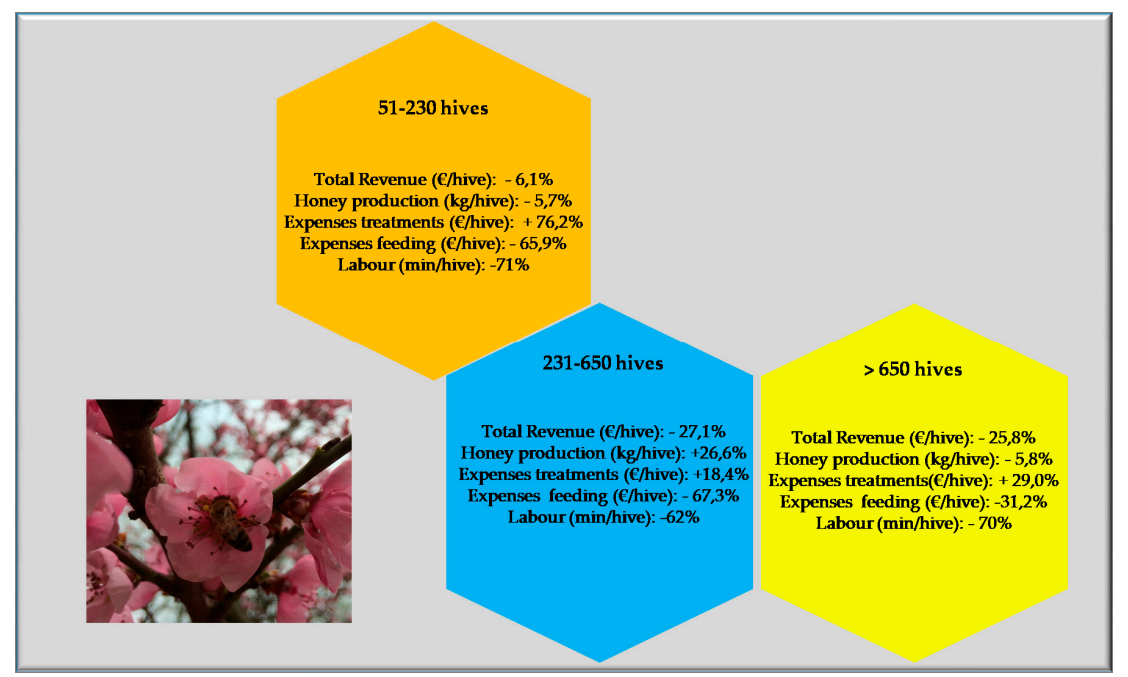

Figure 5. Economic performance of beekeeping farms adopting the chemical $(\mathrm{CH})$ Varroa control in comparison with TBR.

\section{Discussion}

Varroa is one of the major threats that affect honey bee colonies, and several methods are applied by beekeepers to control Varroa mites, with biotechnical practices such as total brood removal being preferable to chemical approaches [13,28-30].

Some studies on the economic results of beekeeping have been performed [40-42], which have focused on costs and revenues obtained by beekeeping activity at the national level and on exploring the societal role of this activity, especially related to pollination services and/or income improvement. Meanwhile, the present study concentrates on the economic aspects of the adoption of biotechniques and the other common control methods used for Varroa mite control in Italian beekeeping farm case studies. The research addressed total brood removal (TBR) as an innovative biotechnique for a sustainable management. A strategic point is that biotechniques are very important in fighting Varroa, hence economic data, even if only preliminary, can be a useful tool.

This study showed that most of the analyzed beekeeping farms adopted TBR for Varroa control on only a proportion of the managed hives (12-36\%), while only one farm applied the technique on all hives. The value of the indexes was not correlated with the number of hives where TBR was adopted, nor with the size of the farm. Furthermore, farm organization was very diversified due to the strong heterogeneity of beekeeping farms.

The results allow a positive evaluation of TBR, in particular:

(1) In all the classes identified, the use of TBR, compared with other techniques, led to an increase in total revenue varying from $11 \%$ to $28 \%$. The difference is due to multiple factors such as the average honey production per hive, the variation in bee stock, the types of production, and the sales channels adopted (wholesale or retail). The prices of bee products (honey, wax, pollen, royal jelly, and propolis) obtained by biotechniques were higher (up $+10 \%$ to $+30 \%$ more, at wholesale price) because of the absence of residues. This also allows these bee products to be presented in the market as organic. Farms operating under organic farming regimes are also encouraged to adopt biotechniques rather than common, legal commercial treatments, because it is possible to obtain a supplemental income (nucleus sale/colony stock conservation). This addresses the behavior of beekeepers, who are increasingly interested in the quality of honey as well as other bee products, because quality is an attribute gaining consideration by consumers, as shown in $[5,7,8]$. Furthermore, if carried out at an early stage, the TBR technique can lead to a reduction in honey production compared to hives managed by other methods. However, this reduction may be compensated by the production of new nuclei; 
(2) The increase in nucleus income is closely related to the survival of the newly formed nuclei, which is influenced by the way in which the technique is performed, the period of formation of the nuclei, the mating of the queens, and environmental conditions. The total expenses for surplus material and manpower (time), as well as possible lower honey production, have a greater impact on the gross income of the nucleus. In addition, formation of nuclei during the spring and summer leads to initial control in the Varroa population of mother colonies and, moreover, the nuclei produce new colonies that can replace winter losses. It should be noted that a higher profit for each nucleus does not necessarily correspond to a satisfactory final result, since the survival rate of the nuclei present at the end of the bee season must be taken into account;

(3) These ecological alternatives need more manpower time (a range from $+37 \%$ up to $+134 \%$ ) in all classes of hive. The TBR requires more labor than the other investigated management techniques (QC, RC, and THY). Manpower is obviously a crucial item, both from a management and an item cost point of view. In comparison with the perception that emerged in the EU Commission Report [1], in which $19 \%$ of beekeepers stated that the administration of medicines to control Varroa is very expensive (more than $20 \%$ of the cost of production), the adoption of a biotechnique may be assessed. The labor required to carry out the different Varroa management techniques varied between farms, and this variability is due to both the use of different techniques and the execution of the same technique in different ways depending on the farm organization and the beekeeper's practicality. The number of hives on which to apply this technique will have to be assessed according to the organization of the farm, the availability of manpower, and beekeeping material;

(4) High expenses were due to the feed distributed to colonies and nuclei. The amount of syrup and candy varied according to the availability of nectar resources in the environment surrounding the apiary, the strength of the colonies, and the use of combs or frames with foundations, because the use of foundations necessarily leads to a higher consumption of feeding/hive stocks for the construction of the combs;

(5) The biotechnique approach was influenced by external factors (climatic conditions, nectar and pollen sources, etc.), related colony conditions, and the knowledge, education, and technical skills of beekeepers [44].

Observations resulting from the performed analysis concern the economic evaluation of the honey bee colony stock present at the beginning and at the end of the year and especially during the year. It was very difficult to quantify the monetary value of the honey bee colony stock. An improvement in the calculation methodology is needed.

This work provides beekeepers with a decision-making tool to help them plan their future management. With regard to the use of TBR, farms will be able to choose the number of hives for which to apply this technique according to their needs and organization. The advantages of biotechniques result from the absence of synthetic acaricides, which lead to the preservation of honey bee health, human health, and the environment, both immediately and in the long term. From an economic point of view, is difficult to monetize this positive impact, but the use of biotechniques allows the production of new nuclei that maintain the bee stock and counteract the decline in honey bees, enhancing their contributions to crop yield, quality, and market value [45-48]. Furthermore, the use of sustainable products with low environmental impact and the consequent limitation of resistance to synthetic acaricides could make the beekeeping farms more resilient over time. One limitation of this work is definitely the small number of case studies. TBR is an innovative practice that is not yet widespread, though study of the few available cases has provided a significant contribution to knowledge of the management and economic impacts on the beekeeping farms that have adopted it. Another limitation is that to our best knowledge, extensive studies about biotechniques providing scientific confirmation of the empirical beekeeper data are lacking. Further investigations on beekeeping farms adopting biotechniques could be carried out in order to expand the dataset. The perceptions of beekeepers 
regarding the feasibility of adopting TBR in relation to farm resources and organization also need to be explored.

Author Contributions: Conceptualization, T.M.; methodology, T.M., M.V., and L.C.; formal analysis T.M.; validation, T.M.; investigation, M.V. and L.C.; data curation, L.C. and M.V.; writing-original draft preparation, T.M., M.V., and L.C.; writing-review and editing, T.M. and M.V.; supervision, T.M.; project administration, T.M.; funding acquisition, T.M. All authors have read and agreed to the published version of the manuscript.

Funding: This research was funded by the European Union, INTERREG V-A France-Italie (ALCOTRA) (2014-2020) -“INNOV'API (n. 1580)—Innovation sanitaire pour la durabilité des exploitations apicoles".

Acknowledgments: The authors thank all the Beekeepers that supplied the data of their farms and Marco Bergero, the technicians of ASPROMIELE, the Beekeepers Association of Piedmont (Italy), and the UNAAPI, the Beekeepers National Association (and Partner of the Innov'Api Project) for providing the contact of the beekeeping farms.

Conflicts of Interest: The authors declare no conflict of interest. The funder had no role in the design of the study; in the collection, analyses, or interpretation of data; in the writing of the manuscript, or in the decision to publish the results.

Photo Credit: Monica Vercelli.

\section{References}

1. Deloitte. The place of the EU in the worldwide honey market. In European Commission DG Agriculture and Rural Development Evaluation of Measures for the Apiculture Sector; Final report; European Commision: Brussels, Belgium, 2013; pp. 29-38.

2. Carreck, N.L. Special issue: Honey. J. Apic. Res. 2018, 57, 1-4. [CrossRef]

3. Chauzat, M.P.; Cauquil, L.; Roy, L.; Franco, S.; Hendrikx, P.; Ribière-Chabert, M. Demographics of the European apicultural industry. PLoS ONE 2013, 8. [CrossRef]

4. Pippinato, L.; Di Vita, G.; Brun, F. Trade and comparative advantage analysis of the eu honey sector with a focus on the italian market. Qual. Success 2019, 20, 485-492.

5. Brščić, K.; Šugar, T.; Poljuha, D. An empirical examination of consumer preferences for honey in Croatia. Appl. Econ. 2017, 49, 5877-5889. [CrossRef]

6. Ványi, G.Á.; Csapó, Z.; Kárpáti, L. Evaluation of consumers' honey purchase habits in Hungary. J. Food Prod. Mark. 2011, 17, 227-240. [CrossRef]

7. Yeow, S.H.C.; Chin, S.T.S.; Yeow, J.A.; Tan, K.S. Consumer purchase intentions and honey related products. J. Mark. Res. Case Stud. 2013, 1, 332-345. [CrossRef]

8. Cosmina, M.; Gallenti, G.; Marangon, F.; Troiano, S. Reprint of "Attitudes towards honey among Italian consumers: A choice experiment approach". Appetite 2016, 106, 110-116. [CrossRef]

9. Wu, S.; Fooks, J.R.; Messer, K.D.; Delaney, D. Consumer demand for local honey. Appl. Econ. 2015, 47, 4377-4394. [CrossRef]

10. Potts, S.G.; Biesmeijer, J.C.; Kremen, C.; Neumann, P.; Schweiger, O.; Kunin, W.E. Global pollinator declines: Trends, impacts and drivers. Trends Ecol. Evol. 2010, 25, 345-353. [CrossRef]

11. Goulson, D.; Nicholls, E.; Botías, C.; Rotheray, E.L. Bee declines driven by combined Stress from parasites, pesticides, and lack of flowers. Science 2015, 347, 1255957. [CrossRef]

12. Jacques, A.; Laurent, M.; Ribiere-Chabert, M.; Saussac, M.; Bougeard, S.; Hendrikx, P.; Chauzat, M. Statistical analysis on the EPILOBEE dataset: Explanatory variables related to honeybee colony mortality in EU during a 2 year survey. EFSA Support. Publ. 2016, 13. [CrossRef]

13. Rosenkranz, P.; Aumeier, P.; Ziegelmann, B. Biology and control of Varroa destructor. J. Invertebr. Pathol. 2010, 103, S96-S119. [CrossRef]

14. Mondet, F.; de Miranda, J.R.; Kretzschmar, A.; Le Conte, Y.; Mercer, A.R. On the front line: Quantitative virus dynamics in honeybee (Apis mellifera L.) Colonies along a new expansion front of the parasite Varroa destructor. PLoS ONE Pathog. 2014, 10, e1004323. [CrossRef]

15. Nazzi, F.; Le Conte, Y. Ecology of Varroa destructor, the major ectoparasite of the western honey bee, Apis mellifera. Annu. Rev. Entomol. 2016, 61, 417-432. [CrossRef]

16. Barroso-Arévalo, S.; Fernández-Carrión, E.; Goyache, J.; Molero, F.; Puerta, F.; Sánchez-Vizcaíno, J.M. High load of deformed wing virus and Varroa destructor infestation are related to weakness of honey bee colonies in Southern Spain. Front. Microbiol. 2019, 10. [CrossRef] 
17. Dietemann, V.; Nazzi, F.; Martin, S.J.; Anderson, D.L.; Locke, B.; Delaplane, K.S.; Wauquiez, Q.; Tannahill, C.; Frey, E.; Ziegelmann, B.; et al. Standard methods for varroa research. J. Apic. Res. 2013, 52, 1-54. [CrossRef]

18. Lindberg, C.M.; Melathopoulos, A.P.; Winston, M.L. Laboratory evaluation of miticides to Control Varroa jacobsoni (Acari: Varroidae), a honey bee (Hymenoptera: Apidae) parasite. J. Econ. Entomol. 2000, 93, 189-198. [CrossRef]

19. Loucif-Ayad, W.; Aribi, N.; Smagghe, G.; Soltani, N. Comparative effectiveness of some acaricides used to control Varroa destructor (Mesostigmata: Varroidae) in Algeria. Afr. Entomol. 2010, 18, 259-266. [CrossRef]

20. Elzen, P.J.; Baxter, J.R.; Spivak, M.; Wilson, W.T. Control of Varroa jacobsoni Oud. resistant to fluvalinate and amitraz using coumaphos. Apidologie 2000, 31, 437-441. [CrossRef]

21. Maggi, M.D.; Ruffinengo, S.R.; Damiani, N.; Sardella, N.H.; Eguaras, M.J. First detection of Varroa destructor resistance to coumaphos in Argentina. Exp. Appl. Acarol. 2009, 47, 317-320. [CrossRef]

22. González-Cabrera, J.; Davies, T.G.E.; Field, L.M.; Kennedy, P.J.; Williamson, M.S. An amino acid substitution (L925V) associated with resistance to pyrethroids in Varroa destructor. PLoS ONE 2013, 8. [CrossRef]

23. Floris, I.; Satta, A.; Cabras, P.; Garau, V.L.; Angioni, A. Comparison between two thymol formulations in the control of Varroa destructor: Effectiveness, persistence, and residues. J. Econ. Entomol. 2004, 97, 187-191. [CrossRef]

24. Adjlane, N.; Tarek, E.O.; Haddad, N. Evaluation of oxalic acid treatments against the mite Varroa destructor and secondary effects on honey bees Apis mellifera. J. Arthropod. Borne. Dis. 2016, 10, 501-509.

25. Gregorc, A.; Adamczyk, J.; Kapun, S.; Planinc, I. Integrated varroa control in honey bee (Apis mellifera carnica) colonies with or without brood. J. Apic. Res. 2016, 55, 253-258. [CrossRef]

26. Pusceddu, M.; Piluzza, G.; Theodorou, P.; Buffa, F.; Ruiu, L.; Bullitta, S.; Floris, I.; Satta, A. Resin foraging dynamics in Varroa destructor-infested hives: A case of medication of kin? Insect Sci. 2017, 26, 297-310. [CrossRef]

27. Delaplane, K.S.; Berry, J.A.; Skinner, J.A.; Parkman, J.P.; Hood, W.M. Integrated pest management against Varroa destructor reduces colony mite levels and delays treatment threshold. J. Apic. Res. 2005, 44, 157-162. [CrossRef]

28. Calderone, N.W. Evaluation of drone brood removal for management of Varroa destructor (Acari: Varroidae) in colonies of Apis mellifera (Hymenoptera: Apidae) in the Northeastern United States. J. Econ. Entomol. 2005, 98, 645-650. [CrossRef]

29. Giacomelli, A.; Pietropaoli, M.; Carvelli, A.; Iacoponi, F.; Formato, G. Combination of thymol treatment (Apiguard ${ }^{\circledR}$ ) and caging the queen technique to fight Varroa destructor. Apidologie 2016, 47, 606-616. [CrossRef]

30. Gregorc, A.; Alburaki, M.; Werle, C.; Knight, P.R.; Adamczyk, J. Brood removal or queen caging combined with oxalic acid treatment to control varroa mites (Varroa destructor) in honey bee colonies (Apis mellifera). Apidologie 2017, 48, 821-832. [CrossRef]

31. Fries, I. Coordination in Europe of Integrated Control of Varroa Mites in Honey Bee Colonies; Final Technical Report for the period from 98-01-01 to 99-12-31; European Commision: Brussels, Belgium, 1999.

32. Pilati, L.; Prestamburgo, M. Sequential relationship between profitability and sustainability: The Case of Migratory Beekeeping. Sustainability 2016, 8, 94. [CrossRef]

33. Stenchly, K.; Hansen, M.V.; Stein, K.; Buerkert, A.; Loewenstein, W. Income vulnerability of West African farming households to losses in pollination services: A case study from Ouagadougou, Burkina Faso. Sustainability 2018, 10, 4253. [CrossRef]

34. Blanc, S.; Brun, F.; Di Vita, G.; Mosso, A. Traditional beekeeping in rural areas: Profitability analysis and feasibility of pollination service. Qual. Success 2018, 19, 72-79.

35. Hein, L. The economic value of the pollination service, a review across scales. Open Ecol. J. 2009, $2,74-82$. [CrossRef]

36. Pejin, B.; Vujisic, L.; Sabovljevic, M.; Tesevic, V.; Vajs, V. Preliminary data on essential oil composition of the moss Rhodobryum ontariense (Kindb.) Kindb. Cryptogam. Bryol. 2011, 32, 113-117. [CrossRef]

37. Nikolić, M.; Marković, T.; Mojović, M.; Pejin, B.; Savić, A.; Perić, T.; Soković, M. Chemical composition and biological activity of Gaultheria procumbens L. essential oil. Ind. Crops Prod. 2013, 49, 561-567.

38. Gallai, N.; Salles, J.M.; Settele, J.; Vaissière, B.E. Economic valuation of the vulnerability of world agriculture confronted with pollinator decline. Ecol. Econ. 2009, 68, 810-821. [CrossRef]

39. Breeze, T.D.; Dean, R.; Potts, S.G. The costs of beekeeping for pollination services in the UK-an explorative study. J. Apic. Res. 2017, 56, 310-317. [CrossRef] 
40. Saner, G.; Engindeniz, S.; Tolon, B.; Cukur, F. The economic analysis of beekeeping enterprise in sustainable development: The case study of Turkey. Apiacta 2004, 38, 342-351.

41. Güemes-Ricalde, F.J.; Villanueva-G, R.; Echazarreta-González, C.; Gómez-Alvarez, R.; Pat-Fernández, J.M. Production costs of conventional and organic honey in the Yucatán peninsula of Mexico. J. Apic. Res. 2006, 45, 106-111. [CrossRef]

42. Vaziritabar, S.; Mehdi Esmaeilzade, S.; Shakib Vaziritabar, C. Profitability and socio-economic analysis of beekeeping and honey production in Karaj state, Iran. J. Entomol. Zool. Stud. 2016, 4, 1341-1350.

43. Iacoponi, L.; Romiti, R. Economia e Politica Agraria; Edagricole: Bologna, Italy, 2001; ISBN 9788820638764.

44. Jacques, A.; Laurent, M.; Ribière-Chabert, M.; Saussac, M.; Bougeard, S.; Budge, G.E.; Hendrikx, P.; Chauzat, M.P. A pan-European epidemiological study reveals honey bee colony survival depends on beekeeper education and disease control. PLoS ONE 2017, 12. [CrossRef]

45. Bommarco, R.; Marini, L.; Vaissière, B.E. Insect pollination enhances seed yield, quality, and market value in oilseed rape. Oecologia 2012, 169, 1025-1032. [CrossRef]

46. Garibaldi, L.A.; Carvalheiro, L.G.; Leonhardt, S.D.; Aizen, M.A.; Blaauw, B.R.; Isaacs, R.; Kuhlmann, M.; Kleijn, D.; Klein, A.M.; Kremen, C.; et al. From research to action: Enhancing crop yield through wild pollinators. Front. Ecol. Environ. 2014, 12, 439-447. [CrossRef]

47. Ferrazzi, P.; Vercelli, M.; Chakir, A.; Romane, A.; Mattana, M.; Consonni, R. Pollination effects on antioxidant content of Perilla frutescens seeds analysed by NMR spectroscopy. Nat. Prod. Res. 2017, 31, 2705-2711. [CrossRef]

48. Klein, A.M.; Vaissière, B.E.; Cane, J.H.; Steffan-Dewenter, I.; Cunningham, S.A.; Kremen, C.; Tscharntke, T. Importance of pollinators in changing landscapes for world crops. Proc. R. Soc. B Biol. Sci. 2007, 274, 303-313. [CrossRef]

(C) 2020 by the authors. Licensee MDPI, Basel, Switzerland. This article is an open access article distributed under the terms and conditions of the Creative Commons Attribution (CC BY) license (http://creativecommons.org/licenses/by/4.0/). 